\title{
Flindersiella endophytica gen. nov., sp. nov., an endophytic actinobacterium isolated from the root of Grey Box, an endemic eucalyptus tree
}

\author{
Onuma Kaewklat and Christopher M. M. Franco \\ Department of Medical Biotechnology, School of Medicine, Flinders University, Bedford Park \\ SA 5042, Australia
}

Correspondence

Christopher M. M. Franco

Chris.Franco@flinders.edu.au

\begin{abstract}
A novel endophytic actinobacterium, designated strain EUM $378^{\top}$, was isolated from the surface-sterilized root tissue of Eucalyptus microcarpa, a eucalyptus tree known as Grey Box. Phylogenetic evaluation based on 16S rRNA gene sequence analysis, including alignment with taxon-specific 16S rRNA gene signature nucleotides, placed this isolate as a member of the family Nocardioidaceae. Strain EUM $378^{\top}$ showed $>5.5 \% 16 \mathrm{~S}$ rRNA gene sequence divergence from other members of this family and was related most closely to Actinopolymorpha alba YIM $48868^{\top}$ (94.2\%) and Actinopolymorpha singaporensis IM $7744^{\top}$ (94.4\%). This Gram-positive, aerobic actinobacterium has well-developed substrate mycelia that fragment into small rods. Chemotaxonomic data revealed that the cell wall contains LL-diaminopimelic acid, ribose, glucose and rhamnose. MK-10 $\left(\mathrm{H}_{6}\right)$ is the predominant menaquinone. Chemotaxonomic and phylogenetic evidence confirmed that strain EUM $378^{\top}$ represents a novel species of a new genus, for which the name Flindersiella endophytica gen. nov., sp. nov. is proposed. The type strain is EUM $378^{\top}$ $\left(=\mathrm{DSM} 45355^{\mathrm{T}}=\right.$ ACM $\left.5289^{\mathrm{T}}\right)$.
\end{abstract}

The family Nocardioidaceae was proposed by Nesterenko et al. (1985), with two genera, Nocardioides (Prauser, 1976) and Pimelobacter (Suzuki \& Komagata, 1983), belonging to this family. Later, the species of the genus Pimelobacter were reclassified to the genera Terrabacter and Nocardioides (Collins et al., 1989). At the time of writing, the family Nocardioidaceae comprises six genera: Nocardioides, Aeromicrobium (Miller et al., 1991), Kribbella (Park et al., 1999), Marmoricola (Urzì et al., 2000), Actinopolymorpha (Wang et al., 2001) and Jiangella (Song et al., 2005).

During the course of our research to identify endophytic actinobacteria from Australian plants using molecular- and culture-based methods (Conn \& Franco, 2004; Coombs \& Franco, 2003), an endophytic nocardioform-like strain (EUM $378^{\mathrm{T}}$ ) was isolated from the surface-sterilized root tissue of an endemic Australian tree, Eucalyptus microcarpa, known as Grey Box. Detailed polyphasic taxonomic analysis revealed that this strain forms a novel taxon

Abbreviations: $A_{2} p m$, diaminopimelic acid; $E S I$, electrospray mass spectrometry; HPDA, half-strength potato dextrose agar; NA, nutrient agar; SEM, scanning electron microscopy.

tPresent address: Department of Biology, Faculty of Science, Mahasarakham University, Mahasarakham province, 44150, Thailand.

The GenBank/EMBL/DDBJ accession number for the 16S rRNA gene sequence of strain EUM $378^{\top}$ is FJ805430.

Supplementary tables and figures are available with the online version of this paper. within the family Nocardioidaceae for which the name Flindersiella gen. nov. is proposed, with the type species Flindersiella endophytica sp. nov.

Root samples of a Grey Box (E. microcarpa) tree were collected from the grounds of the Flinders University campus, Adelaide, South Australia, and processed within $4 \mathrm{~h}$. The bark was removed from the roots and the samples were sterilized with $70 \%$ ethanol and $6 \%$ hypochlorite for 5 min each, washed thoroughly with sterile water and then treated with sterile $10 \% \mathrm{NaHCO}_{3}$ for 10 min before being washed with sterile water. The root tissue was crushed in a sterile mortar and pestle and plated onto VL70 medium containing a mixture of 17 aa and solidified with $0.8 \%$ gellan gum (Hudson et al., 1989; Schoenborn et al., 2004; Song et al., 2005). The $\mathrm{pH}$ was adjusted to 7.2. The medium was supplemented with $20 \mu \mathrm{g}$ nalidixic acid $\mathrm{ml}^{-1}$ and $100 \mathrm{U}$ nystatin $\mathrm{ml}^{-1}$ to control bacterial and fungal contamination, respectively. Plates were kept in plastic sealed boxes that contained moist paper towels to maintain moisture, and incubated at $27{ }^{\circ} \mathrm{C}$ for 16 weeks. One actinobacterium-like strain, EUM $378^{\mathrm{T}}$, emerged from the surface-sterilized internal root tissue of the Grey Box tree (E. microcarpa) after incubation for 12 weeks.

Extraction of genomic DNA from strain EUM $378^{\mathrm{T}}$ and amplification and sequencing of the 16S rRNA gene were carried out as described previously (Coombs \& Franco, 2003). The nearly complete resultant $16 \mathrm{~S}$ rRNA gene sequence (1401 bp) of strain EUM $378^{\mathrm{T}}$ was analysed using 
BLAST (Altschul et al., 1997) and subsequently aligned with the 16S rRNA gene sequences of representatives of related genera available from GenBank by using CLUSTAL_X (Thompson et al., 1997), with Streptomyces griseus NRRL $\mathrm{B}-2165^{\mathrm{T}}$ as the outgroup. Phylogenetic trees were constructed by the neighbour-joining (Saitou \& Nei, 1987) and maximum-parsimony (Kluge \& Farris, 1969) tree-making methods by using the software package MEGA version 4 (Tamura et al., 2007). Pairwise distances for the neighbourjoining algorithm were calculated according to the Kimura two-parameter model (Kimura, 1980), and close-neighbour interchange (search level $=2$, random addition $=100$ ) was applied in maximum-parsimony analysis. The topology of the tree was evaluated by performing a bootstrap analysis (Felsenstein, 1985) based on 1000 replications.

The phylogenetic position of strain EUM $378^{\mathrm{T}}$ was determined by analysis of the almost-complete $16 \mathrm{~S}$ rRNA gene sequence (GenBank accession no. FJ805430) with sequences of representative members of the family Nocardioidaceae. This evaluation shows clearly that strain EUM $378^{\mathrm{T}}$ resides within this family, but shows a line of descent distinct from other validly described members (Fig. 1; Supplementary Fig. S2, available in IJSEM Online). This strain forms a new cluster with its closest neighbours Actinopolymorpha alba YIM $48868^{\mathrm{T}}$, Actinopolymorpha singaporensis IM $7744^{\mathrm{T}}$, Actinopolymorpha cephalotaxi $06-2230^{\mathrm{T}}$ and Actinopolymorpha rutila YIM $45725^{\mathrm{T}}$, with low nucleotide sequence similarity $(94.2,94.4,94.5$ and
$94.4 \%$, respectively). The closest neighbouring genus was Jiangella, sharing only $91 \% 16 \mathrm{~S}$ rRNA gene sequence similarity. Analysis of $16 \mathrm{~S}$ rRNA gene signature nucleotides of strain EUM $378^{\mathrm{T}}$ confirmed that this isolate belongs to the family Nocardioidaceae (Zhi et al., 2009).

DNA-relatedness studies were not carried out between strain EUM $378^{\mathrm{T}}$ and its closest phylogenetic relatives, as the relatively low level of 16S rRNA gene sequence similarity, of $<95 \%$, clearly differentiated strain EUM $378^{\mathrm{T}}$ from its closest neighbours and is lower than the cutoff point recommended for delineation of genomic species (Stackebrandt \& Goebel, 1994).

The $\mathrm{G}+\mathrm{C}$ content of the DNA of strain EUM $378^{\mathrm{T}}$ was determined by HPLC (Mesbah et al., 1989) to be $68.8 \mathrm{~mol} \%$.

For the analysis of whole-cell fatty acids, strain EUM $378^{\mathrm{T}}$ and all four Actinopolymorpha type strains were grown for 10 days at $25{ }^{\circ} \mathrm{C}$ in tryptic soya broth at 150 r.p.m. and harvested by centrifugation at $5000 \mathrm{~g}$. Washed cells $(100 \mathrm{mg})$ were saponified, methylated and extracted and the fatty acid methyl esters were determined by following the protocols described by Microbial Identification Inc. (MIDI) using the Sherlock Microbial Identification System (Sasser, 2001). Extraction and purification of isoprenoid quinones were performed by using the method of Collins et al. (1977) and analysis of the samples was by reversephase LC-MS employing UV detection and electrospray mass spectrometry (ESI). The LC solvent system was

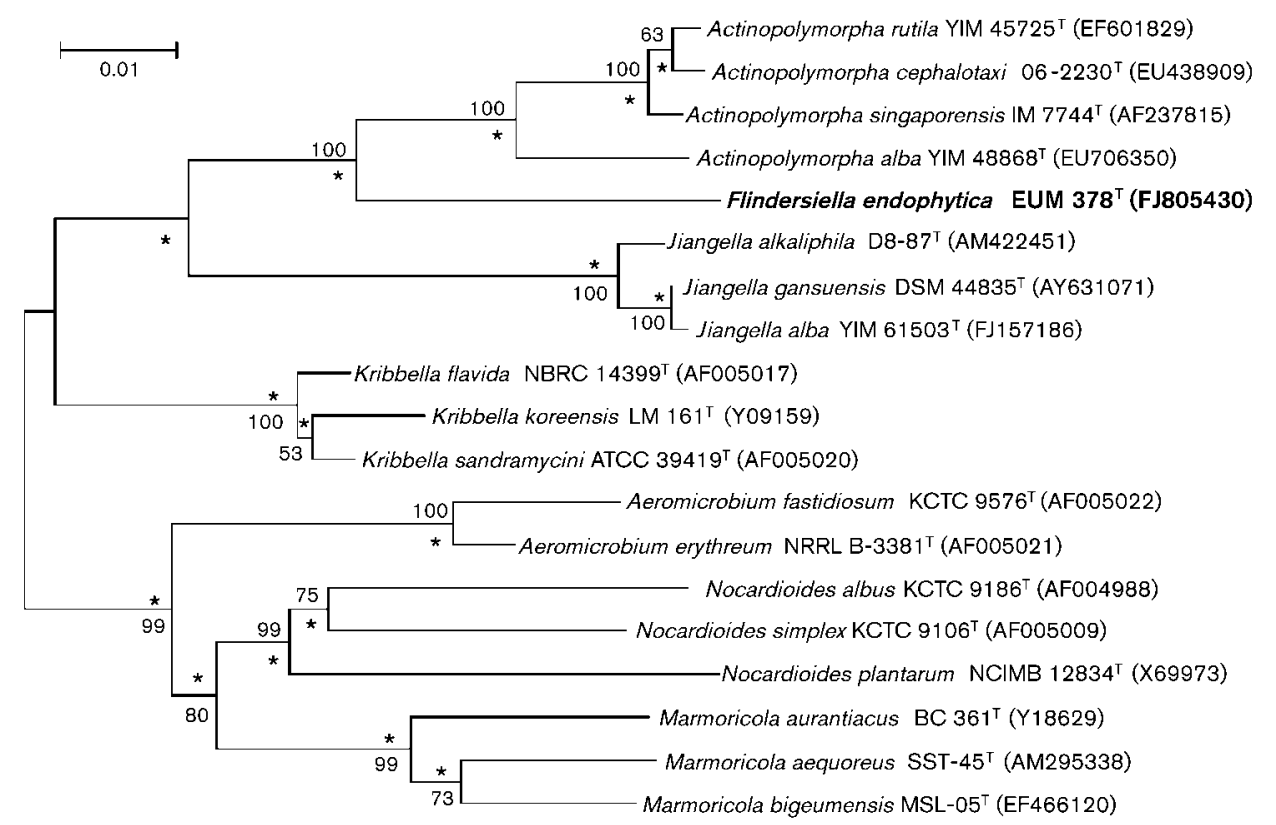

Fig. 1. 16S rRNA gene-based neighbour-joining tree showing the phylogenetic relationships between Flindersiella endophytica EUM $378^{\top}$ and selected micro-organisms belonging to the family Nocardioidaceae. Asterisks indicate branches of the tree that were also recovered by using the maximum-parsimony algorithm (Supplementary Fig. S2, available in IJSEM Online). The length of the sequences is $1390 \mathrm{bp}$. Numbers on the branches indicate percentage bootstrap values of 1000 replicates. Bar, 0.01 changes per nucleotide. 
2-propanol:methanol $(1: 1)$ at a flow rate of 1.0 $\mathrm{ml} \mathrm{min}{ }^{-1}$. Polar lipids were extracted and purified as described by Minnikin et al. (1984). Analysis of the samples was by LC-MS employing an SGE Wakosil C18 HPLC column $(150 \times 2 \mathrm{~mm})$, UV detection at $210 \mathrm{~nm}$ and ESI. Isocratic elution was performed with a solvent consisting of acetonitrile:methanol $(3: 7)$ containing $5 \mu \mathrm{M}$ ethanolamine at a flow rate of $0.2 \mathrm{ml} \mathrm{m^{-1 }}$ (Brouwers et al., 1999; Fang \& Barcelona, 1998; Mazzella et al., 2004). Whole-cell hydrolysates were analysed for diaminopimelic acid $\left(\mathrm{A}_{2} \mathrm{pm}\right)$ isomers by TLC (Bousfield et al., 1985) and for sugars using the method of Hasegawa et al. (1983). Mycolic acid was determined according to Minnikin et al. (1975, 1980 ) and acyl cell-wall analysis was performed according to Uchida \& Seino (1997). The $\mathrm{A}_{2} \mathrm{pm}$ in whole-cell hydrolysates of strain EUM $378^{\mathrm{T}}$ was in the LL configuration, and the whole-cell sugars were ribose, glucose and rhamnose. Strain EUM $378^{\mathrm{T}}$ contained MK-10 $\left(\mathrm{H}_{6}\right)$ as the predominant menaquinone, with $\mathrm{MK}-10\left(\mathrm{H}_{8}\right), \mathrm{MK}-10\left(\mathrm{H}_{4}\right)$ and MK-10 $\left(\mathrm{H}_{2}\right)$ present in small amounts. Phospholipids present were diphosphatidylglycerol and phosphatidylglycerol. The cell wall of strain EUM $378^{\mathrm{T}}$ was of the nonmycolate and acetyl type, and the whole-cell fatty acid pattern was of the iso-anteiso-branched type. The predominant cellular fatty acid of this strain was iso- $\mathrm{C}_{16: 0}$ $(34.65 \%)$; the fatty acid composition is shown in Supplementary Table S1, available in IJSEM Online.

Morphological characteristics of strain EUM $378^{\mathrm{T}}$ and related type strains were observed by comparison on eight different media: five recommended by the International Streptomyces Project (ISP) (Shirling \& Gottlieb, 1966), i.e. ISP 2, 3, 4, 5 and 7, plus Bennett's agar, half-strength potato dextrose agar (HPDA) and nutrient agar (NA) (Atlas, 1993). Cell and spore morphologies of cultures grown on HPDA for 21 days were viewed by scanning electron microscopy (SEM; ETEC Autoscan 1974). Strain EUM $378^{\mathrm{T}}$ showed morphology characteristic of a nocardioform actinobacterium with well-developed substrate mycelium, but aerial mycelium formation was only achieved on some media. Spores are tiny rods (approx. $0.25-0.40 \times 0.30 \mu \mathrm{m})$ on short chains that develop from aerial mycelium on colonies cultured on HPDA (see Supplementary Fig. S1, available in IJSEM Online). Colony characteristics on different media are presented in Supplementary Table S2. Colonies varied in colour on different media from yellow to olive green and, after 30 days growth on HPDA, colonies changed to a bluish purple. Also, this strain produced a greyish orange pigment on tyrosine agar.

Physiological and biochemical characterization of strain EUM $378^{\mathrm{T}}$ and A. alba YIM $48868^{\mathrm{T}}$, A. cephalotaxi I06$2230^{\mathrm{T}}$, A. rutila YIM $45725^{\mathrm{T}}$ and A. singaporensis IM $7744^{\mathrm{T}}$ was performed by the following procedures. Acid production from carbohydrates was examined by the methods of Gordon et al. (1974). Growth at different temperatures (15, 27, 37 and $\left.45^{\circ} \mathrm{C}\right), \mathrm{NaCl}$ concentrations $(2,5,10,15$ and $20 \%, \mathrm{w} / \mathrm{v})$ and $\mathrm{pH}(4.0-10.0)$ was assessed after incubation at $27{ }^{\circ} \mathrm{C}$ for $7-14$ days on ISP 2 medium (Kurup \& Schmitt, 1973). Hydrolysis of casein, starch and gelatin, and catalase production were determined as described by Kurup \& Schmitt (1973). Physiological differentiation of strain EUM $378^{\mathrm{T}}$ from the most closely related type strains is shown in Table 1 .

Phenotypic and genotypic data revealed that strain EUM $378^{\mathrm{T}}$ is different from the described Actinopolymorpha species and other members of the family Nocardioidaceae. There are significant differences in culture characteristics between strain EUM $378^{\mathrm{T}}$ and the most closely related type strain, A. alba YIM $48868^{\mathrm{T}}$. For example, the substrate mycelium colour of strain EUM $378^{\mathrm{T}}$ was yellowish white to dark green on a variety of media, whereas for A. alba YIM $48868^{\mathrm{T}}$ it varied from grey-white to milk white. Also, the type strain of $A$. alba did not grow on nutrient agar or ISP 4, whereas strain EUM $378^{\mathrm{T}}$ could grow on these media. Sparse aerial hyphae of the type strain of $A$. alba were observed only on ISP 2, but no aerial hyphae were observed on any other media. On the other hand, aerial mycelia of strain EUM $378^{\mathrm{T}}$ were observed on most media used, except for ISP 5 and NA. The type strain of A. alba produced a brown pigment on tyrosine agar, but strain EUM $378^{\mathrm{T}}$ did not. The type strain of $A$. alba did not produce spores, whereas strain EUM $378^{\mathrm{T}}$ produced spores on four media tested (Supplementary Table S2). Furthermore, physiological properties of

Table 1. Physiological characteristics of Flindersiella endophytica EUM $378^{\top}$ and Actinopolymorpha reference strains

Strains: 1, Flindersiella endophytica EUM $378^{\mathrm{T}} ; 2$, A. alba YIM $48868^{\mathrm{T}}$; 3, A. singaporensis $\mathrm{IM} 7744^{\mathrm{T}} ; 4$, A. cephalotaxi $\mathrm{I} 06-2230^{\mathrm{T}}$; 5 , A. rutila YIM $45725^{\mathrm{T}}$. All data were generated in this study. + , Positive or present; w, weakly positive; -, negative or absent. All strains could decompose gelatin, and catalase activity was positive. All strains could produce acid from $\mathrm{D}$-arabinose, cellobiose, fructose, galactose, glucose, maltose, mannose, ribose, sucrose, trehalose, xylose and salicin, but not from 1,2 propanediol. They could grow at $1 \%(\mathrm{w} / \mathrm{v})$ $\mathrm{NaCl}$. All strains could grow well at pH $6-10$ and at $27{ }^{\circ} \mathrm{C}$.

\begin{tabular}{|lccccc|}
\hline Characteristic & $\mathbf{1}$ & $\mathbf{2}$ & $\mathbf{3}$ & $\mathbf{4}$ & $\mathbf{5}$ \\
\hline $\begin{array}{l}\text { Acid production from: } \\
\quad \text { Dulcitol }\end{array}$ & & & & & \\
myo-Inositol & - & - & $\mathrm{w}$ & - & $\mathrm{W}$ \\
$\quad$ Mannitol & + & $\mathrm{w}$ & + & + & $\mathrm{W}$ \\
Adonitol & + & - & + & + & + \\
Sorbitol & + & + & + & - & + \\
Decomposition of starch & + & - & + & + & + \\
Growth at: & + & - & - & - & - \\
$3 \% \mathrm{NaCl}$ & & & & & \\
$5 \% \mathrm{NaCl}$ & + & - & + & + & + \\
$\mathrm{pH} 5$ & $\mathrm{~W}$ & - & - & + & - \\
$15{ }^{\circ} \mathrm{C}$ & $\mathrm{W}$ & - & $\mathrm{w}$ & + & + \\
$37{ }^{\circ} \mathrm{C}$ & + & - & - & + & + \\
$45{ }^{\circ} \mathrm{C}$ & + & - & + & $\mathrm{w}$ & + \\
& - & - & $\mathrm{w}$ & - & - \\
\hline
\end{tabular}


both strains were different. Strain EUM $378^{\mathrm{T}}$ produced acid from myo-inositol, mannitol and sorbitol, whereas the type strain of $A$. alba showed a weak result for myo-inositol and negative results for mannitol and sorbitol. Growth of strain EUM $378^{\mathrm{T}}$ occurred between pH 5 and 10 and between 15 and $37^{\circ} \mathrm{C}$, whereas A. alba could grow between pH 6 and 10 and at $27^{\circ} \mathrm{C}$ (Table 1$)$.

Chemotaxonomic characteristics differentiated strain EUM $378^{\mathrm{T}}$ from related genera of the family Nocardioidaceae (Table 2). The predominant menaquinone of strain EUM $378^{\mathrm{T}}$ differs from those of Actinopolymorpha spp., as it contains menaquinone MK-10 $\left(\mathrm{H}_{6}\right)$, whereas the four described Actinopolymorpha species have MK-9 $\left(\mathrm{H}_{6}\right)$ or MK-9 $\left(\mathrm{H}_{4}\right)$ (Cao et al., 2009; Wang et al., 2001, 2008; Yuan et al., 2010).

Also, strain EUM $378^{\mathrm{T}}$ can be distinguished from representatives of the genus Actinopolymorpha by its whole-cell fatty acid profile, as it contains iso- $\mathrm{C}_{10: 0}(5.86 \%)$, whereas this fatty acid was detected in low amounts $(0.98 \%)$ in $A$. rutila. In contrast, the four Actinopolymorpha type strains contain iso- $\mathrm{C}_{15: 0}$ and iso- $\mathrm{C}_{17: 0}$ at much higher levels than strain EUM $378^{\mathrm{T}}$ (Supplementary Table S1).

On the basis of phenotypic and genotypic data, strain EUM $378^{\mathrm{T}}$ can be distinguished from all validly described genera of the family Nocardioidaceae. The evidence presented in this study is sufficient to propose a new genus and novel species for strain EUM $378^{\mathrm{T}}$ : Flindersiella endophytica gen. nov., sp. nov.

\section{Description of Flindersiella gen. nov.}

Flindersiella (Flin.der.si.el'la. N.L. fem. dim. n. Flindersiella named after Flinders University, signifying the site of the host tree from which the type strain originated).

Whole-cell hydrolysate of members of the genus contains $\mathrm{A}_{2} \mathrm{pm}$ in the LL configuration, and whole-cell sugars are ribose, glucose and rhamnose. Diphosphatidylglycerol and phosphatidylglycerol are present. The major fatty acids are iso- $\mathrm{C}_{16: 0}$, anteiso- $\mathrm{C}_{17: 0}$, and anteiso- $\mathrm{C}_{15: 0}$. MK-10 $\left(\mathrm{H}_{6}\right)$ is the major menaquinone. The DNA $\mathrm{G}+\mathrm{C}$ content of the type species of this genus is $68.8 \mathrm{~mol} \%$. Phylogenetically, the genus is positioned in the family Nocardioidaceae, as revealed by the presence of family-specific signature nucleotides (Zhi et al., 2009). The type species is Flindersiella endophytica.

\section{Description of Flindersiella endophytica sp. nov.}

Flindersiella endophytica (en.do.phy'ti.ca. Gr. endo within; Gr. phyton plant; L. fem. suff. -ica adjectival suffix used with the sense of belonging to; N.L. fem. adj. endophytica within plant, endophytic, pertaining to the original isolation from plant tissue).

Aerobic, Gram-positive, non-acid-alcohol-fast, catalasepositive actinobacterium. Colony morphology ranges from smooth to rugose. Colonies are white on ISP 4 and yellowish white on ISP 5, Bennett's agar and NA. They are greyish yellow on ISP 3 and ISP 7 and pale yellow on ISP 2 . Colonies are olive green on HPDA and change to a bluish purple colour after 30 days growth. The type strain produces a greyish orange pigment on tyrosine agar. Substrate mycelium develops well on most media, but aerial mycelium is rarely formed. Substrate mycelium is branched with irregular thickness and fragments into short chains or aggregates. Spores are tiny rods on short chains that develop from aerial mycelium. White spores are produced on ISP 3, ISP 4, ISP 7 and HPDA. Grows between 15 and $37^{\circ} \mathrm{C}$, between pH 5.0 and 10.0 and in the presence of up to $5 \%(\mathrm{w} / \mathrm{v}) \mathrm{NaCl}$. Optimum growth is achieved at a temperature of $27-37{ }^{\circ} \mathrm{C}$, between $\mathrm{pH} 6$ and 10 and in the presence of $<3 \%(\mathrm{w} / \mathrm{v}) \mathrm{NaCl}$. Acid production from carbon sources is shown in Table 1.

The type strain, EUM $378^{\mathrm{T}}\left(=\mathrm{DSM} 45355^{\mathrm{T}}=\right.$ ACM $\left.5289^{\mathrm{T}}\right)$, was isolated from surface-sterilized root tissue of a Eucalyptus microcarpa tree that grows on the campus of Flinders University, Adelaide, South Australia. The DNA $\mathrm{G}+\mathrm{C}$ content of the type strain is $68.8 \mathrm{~mol} \%$.

Table 2. Differential characteristics of Flindersiella endophytica EUM $378^{\top}$ and related taxa in the family Nocardioidaceae

\begin{tabular}{|c|c|c|c|c|c|}
\hline Taxon & Cell morphology & $\begin{array}{c}\text { Major } \\
\text { menaquinone }\end{array}$ & Polar lipids ${ }^{\star}$ & $\begin{array}{c}\text { DNA G + C content } \\
(\mathrm{mol} \%)\end{array}$ & Reference \\
\hline Strain EUM $378^{\mathrm{T}}$ & Hyphae, rods & MK-10 $\left(\mathrm{H}_{6}\right)$ & DPG, PG, PI & 68.8 & This study \\
\hline Actinopolymorpha & $\begin{array}{l}\text { Pleomorphism to } \\
\text { hypha }\end{array}$ & $\begin{array}{l}\text { MK-9 }\left(\mathrm{H}_{6}\right) \text { or } \\
\text { MK-9 }\left(\mathrm{H}_{4}\right)\end{array}$ & PIM, DPG & $66.6-69.5$ & $\begin{array}{l}\text { Cao et al. (2009); } \\
\text { Wang et al. }(2001,2008) ; \\
\text { Yuan et al. }(2010)\end{array}$ \\
\hline Jiangella & Hyphae, rods & MK-9 $\left(\mathrm{H}_{4}\right)$ & PI, PIM, PG & 70 & Song et al. (2005) \\
\hline Kribbella & Hyphae, rods, cocci & MK-9 $\left(\mathrm{H}_{4}\right)$ & DPG, PC, PG, PI & $68-71$ & Park et al. (1999) \\
\hline Nocardioides & Hyphae, rods, cocci & MK-8 $\left(\mathrm{H}_{4}\right)$ & PG, DPG, PL, PG-OH & $66.5-71.7$ & Collins et al. (1989) \\
\hline Aeromicrobium & Rods & MK-9 $\left(\mathrm{H}_{4}\right)$ & $\mathrm{PE}, \mathrm{PG}$ & $71-73$ & Miller et al. (1991) \\
\hline Marmoricola & Cocci & MK-8 $\left(\mathrm{H}_{4}\right)$ & PI, DPG, PG & 72 & Urzì et al. (2000) \\
\hline
\end{tabular}

*DPG, Diphosphatidylglycerol; PC, phosphatidylcholine; PE, phosphatidylethanolamine; PG, phosphatidylglycerol; PG-OH, phosphatidylglycerol containing 2-hydroxy fatty acids; PI, phosphatidylinositol; PIM, phosphatidylinositol mannosides; PL, unknown phospholipid(s). 


\section{Acknowledgements}

The authors thank Greg Kirby for his assistance with sampling of native plants, Daniel Jardine for menaquinone and polar lipid analysis and Kerry Gascoigne for SEM visualization. Also, we are grateful to Max Aravena-Roman for performing the MIDI fatty acid analysis, Cheng-Lin Jiang for providing A. alba YIM $48868^{\mathrm{T}}$, Wen-Jun Li for providing A. cephalotaxi $\mathrm{I} 06-2230^{\mathrm{T}}$ and A. rutila YIM $45725^{\mathrm{T}}$, and Yue Wang for providing A. singaporensis IM $7744^{\mathrm{T}}$.

\section{References}

Altschul, S. F., Madden, T. L., Schäffer, A. A., Zhang, J., Zhang, Z., Miller, W. \& Lipman, D. J. (1997). Gapped BLAST and PSI-BLAST: a new generation of protein database search programs. Nucleic Acids Res 25, 3389-3402.

Atlas, R. M. (1993). Handbook of Microbiological Media. Edited by L. C. Parks. Boca Raton, FL: CRC Press.

Bousfield, I. J., Keddie, R. M., Dando, T. R. \& Shaw, S. (1985). Simple rapid methods of cell wall analysis as an aid in the identification of aerobic coryneform bacteria. In Chemical Methods in Bacterial Systematics (Society for Applied Bacteriology Technical Series vol. 20), pp. 221-236. Edited by M. Goodfellow \& D. E. Minnikin. London: Academic Press.

Brouwers, J. F., Vernooij, E. A., Tielens, A. G. \& van Golde, L. M. (1999). Rapid separation and identification of phosphatidylethanolamine molecular species. J Lipid Res 40, 164-169.

Cao, Y. R., Jiang, Y., Wu, J. Y., Xu, L. H. \& Jiang, C. L. (2009). Actinopolymorpha alba sp. nov., isolated from a rhizosphere soil. Int $J$ Syst Evol Microbiol 59, 2200-2203.

Collins, M. D., Pirouz, T., Goodfellow, M. \& Minnikin, D. E. (1977), Distribution of menaquinones in actinomycetes and corynebacteria. J Gen Microbiol 100, 221-230.

Collins, M. D., Dorsch, M. \& Stackebrandt, E. (1989). Transfer of Pimelobacter tumescens to Terrabacter gen. nov. as Terrabacter tumescens comb. nov. and of Pimelobacter jensenii to Nocardioides as Nocardioides jensenii comb. nov. Int J Syst Bacteriol 39, 1-6.

Conn, V. M. \& Franco, C. M. M. (2004). Analysis of the endophytic actinobacterial population in the roots of wheat (Triticum aestivum L.) by terminal restriction fragment length polymorphism and sequencing of $16 \mathrm{~S}$ rRNA clones. Appl Environ Microbiol 70, 1787-1794.

Coombs, J. T. \& Franco, C. M. M. (2003). Isolation and identification of actinobacteria from surface-sterilized wheat roots. Appl Environ Microbiol 69, 5603-5608.

Fang, J. \& Barcelona, M. J. (1998). Structural determination and quantitative analysis of bacterial phospholipids using liquid chromatography/electrospray ionization/mass spectrometry. J Microbiol Methods 33, 23-35.

Felsenstein, J. (1985). Confidence limits on phylogenies: an approach using the bootstrap. Evolution 39, 783-791.

Gordon, R. E., Barnett, D. A., Handerhan, J. E. \& Pang, C. H. (1974). Nocardia coeliaca, Nocardia autotrophica, and the nocardin strain. Int $J$ Syst Bacteriol 24, 54-63.

Hasegawa, T., Takisawa, M. \& Tanida, S. (1983). A rapid analysis for chemical grouping of aerobic actinomycetes. J Gen Appl Microbiol 29, 319-322.

Hudson, J. A., Schofield, K. M., Morgan, H. W. \& Daniel, R. M. (1989). Thermonema lapsum gen. nov., sp. nov., a thermophilic gliding bacterium. Int J Syst Bacteriol 39, 485-487.

Kimura, M. (1980). A simple method for estimating evolutionary rates of base substitutions through comparative studies of nucleotide sequences. J Mol Evol 16, 111-120.
Kluge, A. G. \& Farris, F. S. (1969). Quantitative phyletics and the evolution of anurans. Syst Zool 18, 1-32.

Kornerup, J. \& Wanscher, H. (1978). Methuen Handbook of Colour, 3rd edn. Fakenham, UK: Cox \& Wyman.

Kurup, P. V. \& Schmitt, J. A. (1973). Numerical taxonomy of Nocardia. Can J Microbiol 19, 1035-1048.

Mazzella, N., Molinet, J., Syakti, A. D., Dodi, A., Doumenq, P., Artaud, J. \& Bertrand, J. C. (2004). Bacterial phospholipid molecular species analysis by ion-pair reversed-phase HPLC/ESI/MS. J Lipid Res 45, 1355-1363.

Mesbah, M., Premachandran, U. \& Whitman, W. B. (1989). Precise measurement of the $\mathrm{G}+\mathrm{C}$ content of deoxyribonucleic acid by high performance liquid chromatography. Int J Syst Bacteriol 39, 159-167.

Miller, E. S., Woese, C. R. \& Brenner, S. (1991). Description of the erythromycin-producing bacterium Arthrobacter sp. strain NRRL B3381 as Aeromicrobium erythreum gen. nov., sp. nov. Int J Syst Bacteriol 41, 363-368.

Minnikin, D. E., Alshamaony, L. \& Goodfellow, M. (1975). Differentiation of Mycobacterium, Nocardia, and related taxa by thin-layer chromatographic analysis of whole-organism methanolysates. J Gen Microbiol 88, 200-204.

Minnikin, D. E., Hutchinson, I. G., Caldicott, A. B. \& Goodfellow, M. (1980). Thin layer chromatography of methanolysates of mycolic acid containing bacteria. J Chromatogr A 188, 221-233.

Minnikin, D. E., O’Donnell, A. G., Goodfellow, M., Alderson, G., Athalye, M., Schaal, A. \& Parlett, J. H. (1984). An integrated procedure for the extraction of bacterial isoprenoid quinones and polar lipids. J Microbiol Methods 2, 233-241.

Nesterenko, O. A., Kvasnikov, E. I. \& Nogina, T. M. (1985). Nocardioidaceae fam. nov., a new family of the order Actinomycetales Buchanan 1917. Mikrobiol Zh 47, 3-12.

Park, Y. H., Yoon, J. H., Shin, Y. K., Suzuki, K., Kudo, T., Seino, A., Kim, H. J., Lee, J. S. \& Lee, S. T. (1999). Classification of 'Nocardioides fulvus' IFO 14399 and Nocardioides sp. ATCC 39419 in Kribbella gen. nov., as Kribbella flavida sp. nov. and Kribbella sandramycini sp. nov. Int J Syst Bacteriol 49, 743-752.

Prauser, H. (1976). Nocardioides, a new genus of the order Actinomycetales. Int J Syst Bacteriol 26, 58-65.

Saitou, N. \& Nei, M. (1987). The neighbor-joining method: a new method for reconstructing phylogenetic trees. Mol Biol Evol 4, 406-425.

Sasser, M. (2001). Identification of bacteria by gas chromatography of cellular fatty acids, MIDI Technical Note 101. Newark, DE: MIDI Inc. http://www.microbialid.com/PDF/TechNote_101.pdf.

Schoenborn, L., Yates, P. S., Grinton, B. E., Hugenholtz, P. \& Janssen, P. H. (2004). Liquid serial dilution is inferior to solid media for isolation of cultures representative of the phylum-level diversity of soil bacteria. Appl Environ Microbiol 70, 4363-4366.

Shirling, E. B. \& Gottlieb, D. (1966). Methods for characterization of Streptomyces species. Int J Syst Bacteriol 16, 313-340.

Song, L., Li, W. J., Wang, Q. L., Chen, G. Z., Zhang, Y. S. \& Xu, L. H. (2005). Jiangella gansuensis gen. nov., sp. nov., a novel actinomycete from a desert soil in north-west China. Int J Syst Evol Microbiol 55, 881-884.

Stackebrandt, E. \& Goebel, B. M. (1994). Taxonomic note: A place for DNA-DNA reassociation and 16s rRNA sequence analysis in the present species definition in bacteriology. Int J Syst Bacteriol 44, 846-849.

Suzuki, S. \& Komagata, K. (1983). Pimelobacter gen. nov., a new genus of coryneform bacteria with LL-diaminopimelic acid in the cell wall. J Gen Appl Microbiol 29, 59-71.

Tamura, K., Dudley, J., Nei, M. \& Kumar, S. (2007). MEGA4: Molecular Evolutionary Genetics Analysis (MEGA) software version 4.0. Mol Biol Evol 24, 1596-1599. 
Thompson, J. D., Gibson, T. J., Plewniak, F., Jeanmougin, F. \& Higgins, D. G. (1997). The CLUSTAL_X windows interface: flexible strategies for multiple sequence alignment aided by quality analysis tools. Nucleic Acids Res 25, 4876-4882.

Uchida, K. \& Seino, A. (1997). Intra- and intergenic relationships of various actinomycete strains based on the acyl types of the muramyl residue in cell wall peptidoglycans examined in a glycolate test. Int $J$ Syst Bacteriol 47, 182-190.

Urzì, C., Salamone, P., Schumann, P. \& Stackebrandt, E. (2000). Marmoricola aurantiacus gen. nov., sp. nov., a coccoid member of the family Nocardioidaceae isolated from a marble statue. Int J Syst Evol Microbiol 50, 529-536.

Wang, Y. M., Zhang, Z. S., Xu, X. L., Ruan, J. S. \& Wang, Y. (2001). Actinopolymorpha singaporensis gen. nov., sp. nov., a novel actinomycete from the tropical rainforest of Singapore. Int J Syst Evol Microbiol 51, 467-473.

Wang, Y. X., Zhang, Y. Q., Xu, L. H. \& Li, W. J. (2008). Actinopolymorpha rutila sp. nov., isolated from a forest soil. Int $J$ Syst Evol Microbiol 58, 2443-2446.

Yuan, L. J., Zhang, Y. Q., Yu, L. Y., Sun, C. H., Wei, Y. Z., Liu, H. Y., Li, W. J. \& Zhang, Y. Q. (2010). Actinopolymorpha cephalotaxi sp. nov., a novel actinomycete isolated from rhizosphere soil of the plant Cephalotaxus fortunei. Int J Syst Evol Microbiol 60, 51-54.

Zhi, X. Y., Li, W. J. \& Stackebrandt, E. (2009). An update of the structure and 16S rRNA gene sequence-based definition of higher ranks of the class Actinobacteria, with the proposal of two new suborders and four new families and emended descriptions of the existing higher taxa. Int J Syst Evol Microbiol 59, 589-608. 